Additional Perspectives articles for Influenza: The Cutting Edge book collection are available at http://perspectivesinmedicine.cshlp.org/cgi/collection/influenza_the_cutting_edge.

\title{
Influenza in Children
}

\author{
Jennifer Nayak, ${ }^{1}$ Gregory Hoy, ${ }^{2}$ and Aubree Gordon ${ }^{3}$ \\ ${ }^{1}$ Department of Pediatrics, Division of Pediatric Infectious Diseases, University of Rochester Medical Center, \\ Rochester, New York 14642-0001, USA \\ ${ }^{2}$ Medical Scientist Training Program, Medical School, University of Michigan, Ann Arbor, Michigan \\ 48109-2029, USA \\ ${ }^{3}$ Department of Epidemiology, School of Public Health, University of Michigan, Ann Arbor, Michigan \\ 48109-2029, USA \\ Correspondence: gordonal@umich.edu
}

Influenza poses a significant disease burden on children worldwide, with high rates of hospitalization and substantial morbidity and mortality. Although the clinical presentation of influenza in children has similarities to that seen in adults, there are unique aspects to how children present with infection that are important to recognize. In addition, children play a significant role in viral transmission within communities. Growing evidence supports the idea that early influenza infection can uniquely establish lasting immunologic memory, making an understanding of how viral immunity develops in this population critical to better protect children from infection and to facilitate efforts to develop a more universally protective influenza vaccine.

nfection with influenza is exceedingly common in children worldwide. Globally, the incidence of influenza in children under the age of 5 is estimated to be 90 million cases per year (Nair et al. 2011), with the incidence in children in the United States estimated at 19/1000 per year (Fowlkes et al. 2014). Less than 10\% of children less than 5 yr of age have a laboratory-confirmed influenza health-care visit each year, and an estimated $6 \%-12 \%$ of U.S. children seek care for influenza or an influenza-related illness each year (Neuzil et al. 2002; Poehling et al. 2006). Young children make up the largest proportion of patients seeking influenza-related care, with children less than $5 \mathrm{yr}$ of age hospitalized because of influenza and related conditions at a rate of 1000 per 100,000 person-years (Poehling et al. 2006; Caini et al. 2018). Globally, an estimated 28,000 children less than $18 \mathrm{yr}$ of age die from influenza-related lower respiratory tract infections each year, with the majority of these deaths occurring in children less than 4 yr of age (Troeger et al. 2019). In the United States, the overall cumulative mortality of children with influenza is 0.15 deaths per 100,000 children, with a higher cumulative mortality of 0.66 deaths per 100,000 children in children less than 6 mo of age (Shang et al. 2018). Low-to-middleincome countries (LMICs) are disproportionately affected by influenza-related mortality. The case fatality rate for children with influenza is up to 15 times higher in LMICs than in

Editors: Gabriele Neumann and Yoshihiro Kawaoka

Additional Perspectives on Influenza: The Cutting Edge available at www.perspectivesinmedicine.org

Copyright (C) 2021 Cold Spring Harbor Laboratory Press; all rights reserved; doi: 10.1101/cshperspect.a038430

Cite this article as Cold Spring Harb Perspect Med 2021;11:a038430 
J. Nayak et al.

developed countries, and an estimated $99 \%$ of influenza-related deaths among children younger than 5 yr of age occur in LMICs (Nair et al. 2011).

Influenza infection in children also poses a socioeconomic burden for both children and families. Almost all school-aged children with influenza miss at least a day of school, with influenza infection leading to the highest average days of school missed compared with other common childhood acute respiratory illnesses such as respiratory syncytial virus, human metapneumovirus, parainfluenza virus, and coronavirus (Principi et al. 2003; Ambrose and Antonova 2014; McLean et al. 2017). Furthermore, around one-half of the parents of children with influenza miss at least a day of work, and many others must hire caregivers for sick children. Children with influenza often visit healthcare providers once or more during the course of their illness, which may incur additional costs for the family and place an added burden on a country's health-care system (Ambrose and Antonova 2014).

Assessing the true burden of influenza in the pediatric population is difficult for several reasons. For one, a large proportion of the burden of influenza in children is not from the primary infection, but rather from secondary infections, exacerbations of existing chronic diseases such as asthma or other complications. These complications may not be attributed to influenza even if influenza infection was the initial causal pathogen behind the presentation (Gordon and Reingold 2018). Delayed presentation to healthcare facilities combined with a reliance on molecular testing can also lead to underestimations of burden. Indeed, a recent study that combined molecular and serological testing with wide testing criteria indicated that the burden of severe influenza in infants may be twice that of current global estimates (Thompson et al. 2019). In addition, maternal influenza infection is associated with increased maternal morbidity and mortality, as well as increased occurrence of premature and small-for-gestational-age births. These events may have lifelong health consequences for the child, but assigning causality to influenza is difficult and rarely done (Dodds et al. 2007;
Omer et al. 2011). Even in cases in which influenza virus is confirmed with laboratory testing, the high prevalence of other respiratory viruses in the pediatric population can make the determination of a precise viral etiology difficult (Gordon and Reingold 2018). All of these factors lead to a pediatric influenza burden that is likely underestimated, especially in LMICs in which even the overall incidence of influenza is generally poorly characterized (Widdowson and Monto 2013).

\section{CLINICAL PRESENTATION}

The clinical presentation of influenza in children shares many features with adult influenza. Classically, a child will present with a combination of subjective fever, headache, cough, pharyngitis, and coryza, as well as general malaise, myalgias, and muscle fatigue (Table 1) (Poehling et al. 2006; Silvennoinen et al. 2009; Ruf and Knuf 2014). Clinical signs of influenza include a temperature of $>37.8^{\circ} \mathrm{C}\left(100^{\circ} \mathrm{F}\right)$, clear nasal discharge, and erythematous nasal and pharyngeal membranes without exudate. The lungs are typically clear to auscultation in primary influenza infection, although scattered rhonchi and crackles can occasionally be heard. In addition to these shared features, there are features of influenza in children that are rarely experienced in adult patients. Cervical lymphadenopathy is much more frequently seen in influenza-positive children than adults, and children are more like-

Table 1. Relative occurrence of influenza signs and symptoms in medically attended children

\begin{tabular}{ll}
\hline Subjective fever & Extremely common \\
\hline Temperature $\geq 38^{\circ} \mathrm{C}$ & Very common \\
Cough & Very common \\
Rhinorrhea & Very common \\
Coryza & Very common \\
Headache & Common \\
Myalgia & Uncommon \\
Vomiting/diarrhea & Common \\
Rhonchi/crackles & Uncommon \\
\hline
\end{tabular}

Approximate prevalence of symptoms/signs in children with influenza: uncommon, $0 \%-30 \%$; common, $30 \%-60 \%$; very common, $60 \%-90 \%$; and extremely common, $90 \%-$ $100 \%$. 
ly to have a higher temperature than adults. Furthermore, a significant proportion of children experience gastrointestinal symptoms such as vomiting, diarrhea, and abdominal pain. The pathogenesis of these symptoms is not well-established. Although fecal shedding of influenza virus may be observed, the relationship between fecal shedding and gastrointestinal symptoms is unclear and there is little evidence for direct influenza-mediated damage in the gastrointestinal tract (Minodier et al. 2015).

Although influenza can be devastating as a primary infection, the most feared complications in children typically stem from secondary manifestations of influenza (Table 2). A study conducted in Sweden reported that $41 \%$ of influenza-positive children less than $18 \mathrm{yr}$ of age experienced some form of influenza-related complication (Bennet et al. 2016). The most common complications in children are primary viral or secondary bacterial pneumonia, seizures, other secondary bacterial infections such as sinusitis or acute otitis media, and exacerbation of existing respiratory issues such as asthma (Neuzil et al. 2000b; Zambon 2013; Bennet et al. 2016). Rarer but potentially devastating complications include myalgia with elevated creatinine kinase, Guillain-Barré syndrome (an autoimmune condition characterized by demyelination and loss of function of peripheral motor neurons leading to ascending muscle weakness and paralysis) and Reye's syndrome (Verity et al. 2011; Vellozzi et al. 2014; Sellers et al. 2017). Encephalitis/encephalopathy can also occur, with $>80 \%$ of cases of influenza-associated encephalitis/encephalopathy occurring in children less than $5 \mathrm{yr}$ of age, often with severe resulting morbidity or even mortality (Kasai

Table 2. Relative occurrence of influenza complications in children

\begin{tabular}{ll}
\hline Acute otitis media & Common \\
Bacterial pneumonia & Uncommon \\
Primary viral pneumonia & Uncommon \\
Sinusitis & Uncommon \\
Seizures & Uncommon \\
Encephalitis & Rare
\end{tabular}

Prevalence of complications in children with influenza: rare, $<1 \%$; uncommon, $1 \%-5 \%$; and common, $5 \%-20 \%$. et al. 2000; Britton et al. 2017). Although up to $73 \%$ of Reye's syndrome cases are preceded by influenza, because of the nearly absolute contraindication of aspirin use in children, reports of Reye's syndrome have decreased to one to two cases per year in the United States (Chapman and Arnold 2019).

Many influenza symptoms are nonspecific and may be associated with different respiratory illnesses in children. This, combined with the variance in presentation from completely asymptomatic to severe illness leading to death, makes diagnosis of influenza difficult (Zambon 2013). For example, a study in Nashville, Tennessee found that only $17 \%$ of children with laboratory-confirmed influenza were given a diagnosis of influenza by their physician in the outpatient setting (Poehling et al. 2006). This necessitates the exploration of clinical features that are more highly associated with influenza than other common respiratory illnesses. A study in Nicaragua found that both rhinorrhea and nasal congestion are observed significantly more in febrile children with laboratory-confirmed influenza than in febrile children with noninfluenza illnesses (Gresh et al. 2016). Furthermore, the combination of cough and fever within $48 \mathrm{hr}$ of symptom onset is highly predictive of influenza, as is the concurrent occurrence of cough, headache, and pharyngitis (Monto et al. 2000; Friedman and Attia 2004). Integration of these clinical models as well as further development of point-of-care diagnostic tools may help improve the detection and diagnosis of influenza in children.

There appear to be no significant differences in the clinical presentation of different influenza subtypes, such as seasonal influenza A/B or between seasonal influenza and the 2009 pandemic. Although neurologic complications may be more common in 2009 pandemic influenza, the underlying symptomology is consistent with that of seasonal influenza (Calitri et al. 2010). Age-adjusted rates of complications such as acute otitis media, pneumonia, and sinusitis, as well as metrics of severity such as hospitalizations, intensive care unit (ICU) admissions, mechanical ventilation rates, and absenteeism from school, have not been found to be signifi- 
J. Nayak et al.

cantly different between influenza A and influenza B (Friedman and Attia 2004; Irving et al. 2012; Silvennoinen et al. 2015). Although population-level differences in complications may be present between seasonal and 2009 pandemic influenza, this can be attributed to different patterns of age-group susceptibility rather than underlying differences in the clinical presentation (Silvennoinen et al. 2015).

\section{INFLUENZA TRANSMISSION}

Children, especially those who are of elementary school age and younger, are thought to be primary drivers of influenza transmission within communities. Although adults have a role in transmitting influenza from one geographic location to another because of more frequent travel, children are thought to be the primary facilitators of influenza spread within a given community (Russell et al. 2008; Jernigan and Cox 2013; Worby et al. 2015). The critical role of children in transmitting influenza is also supported by studies showing that vaccination programs targeting school-aged children simultaneously reduce influenza infections and influenza-related primary care physician visits, emergency department visits, and hospitalizations in the unvaccinated adult population (Weycker et al. 2005; Baguelin et al. 2013; Pebody et al. 2015; Wang et al. 2016). In addition, many studies have shown that school closures during both pandemic and epidemic influenza outbreaks reduce transmission of influenza in the entire community, not just among schoolchildren (Cauchemez et al. 2008; Jackson et al. 2013; Ali et al. 2018). Transmission of seasonal influenza from an index case to other members of a household, or secondary influenza transmission, is more likely to occur if the index case is a child when compared with adult index cases (Viboud et al. 2004; Tsang et al. 2015). Notably, this increased influenza transmissibility observed in children may depend on the influenza strain; some studies, particularly studies of 2009 pandemic influenza, found no association between age of the index case and likelihood of transmission (Cauchemez et al. 2009). Literature is also mixed regarding differences in char- acteristics of transmission between influenza A and $B$ and the selective vulnerability, if any, that children have to different strains. Influenza B is generally considered to be more common in children and more difficult to transmit to adults when compared with influenza A (Monto and Kioumehr 1975; Nair et al. 2011; Gordon et al. 2018), however, other evidence suggests that influenza A and B have very similar profiles of transmissibility in both children and adults $(\mathrm{Az}$ man et al. 2013).

There are several proposed explanations for the critical role of children in influenza transmission within communities. In addition to showing increased transmissibility of seasonal influenza, preschool and school-age children are themselves more susceptible to secondary transmission of influenza than adult household members (Viboud et al. 2004; Cauchemez et al. 2009; Casado et al. 2014; Gordon et al. 2018). The observation that children are more likely to become infected with influenza and, once infected, are more likely to transmit the infection to other household members helps explain the central role of children in the circulation of influenza in communities. This, combined with the fact that children spend lots of time with extrahousehold contacts in close-quarter locations such as schools and day-care centers, creates an environment where influenza can quickly propagate through a pediatric population and then transmit the virus to adult family members and other community members (Viboud et al. 2004; Mossong et al. 2008). Furthermore, young children are more likely to practice poor hand hygiene and engage in practices such as touching one's nose, eyes, and mouth and putting objects in one's mouth. Each of these behavioral components may bolster the virus's ability to get from child to child or child to adult (Zomer et al. 2015).

In addition to these social and behavioral factors, observed differences in the duration and timing of viral shedding between children and adults help explain the role of children in influenza transmission. There is evidence that children begin to shed influenza virus for a day or more before becoming symptomatic (Frank et al. 1981; Ng et al. 2016). This contrasts with 
adults, in which presymptomatic viral shedding is shorter and less common. This finding theoretically explains some of the increased transmissibility observed in children, as there is a window of time in which a potentially infectious child may be engaging in typical activities such as attending school or day care while infectious. Furthermore, younger children tend to have a longer duration of viral shedding compared with older children and adults, representing an increased amount of time in which viral transmission can occur ( $\mathrm{Ng}$ et al. 2016; Maier et al. 2018). Further investigation is needed to pinpoint the mechanism for these observations, although the relatively immunologically naive immune system of children has been posited as a possible explanation (Monto 1999; Viboud et al. 2004; Ng et al. 2016). Children may also have finer aerosol particles $(\leq 5 \mu \mathrm{m})$ that may contain a higher density of viral particles (Yang et al. 2011; Milton et al. 2013). It is thus plausible, although not empirically shown, that exhalation of a higher proportion of fine aerosol particles with increased viral density contributes to increased infectivity (Schwarz et al. 2010; Bake et al. 2019).

\section{INFLUENZA PREVENTION}

Currently, annual vaccination is the best way to protect children against seasonal influenza virus infection. Recommendations in the United States are for vaccination of all individuals 6 mo of age and older with inactivated influenza vaccine (IIV), with administration of live attenuated influenza vaccine (LAIV) an option, but only in children $>24$ mo of age owing to a reported increased risk of post-LAIV wheezing in infants (Belshe et al. 2007; Grohskopf et al. 2019). Although several other developed countries, including Canada, also recommend universal vaccination, most countries recommend vaccination for high-risk children only. Children less than $9 \mathrm{yr}$ of age initially receive a priming dose of vaccine followed by a booster dose of vaccine at least $28 \mathrm{~d}$ later as they may be relatively immunologically naive to this virus, with yearly vaccination recommended thereafter (Grohskopf et al. 2019). Because of the circulation of two antigenically distinct lineages of influenza B (Victoria lineage and Yamagata lineage) in humans, many influenza vaccines currently approved for use in children are now quadrivalent (Ambrose and Levin 2012; Paul Glezen et al. 2013). Overall influenza vaccination coverage in children remains suboptimal even though children are considered an at-risk population, with substantial variability by age, location, and season. Between the 2010-2011 and 20172018 influenza seasons in the United States, vaccination coverage ranged between $63.6 \%$ and $70 \%$ for children 6 mo to 4 y of age, but dropped to $33.7 \%$ to $48.8 \%$ among teens (Centers for Disease Control and Prevention 2019). Strikingly, vaccination coverage in 358 laboratory-confirmed influenza-associated pediatric deaths between July 2010 and June 2014 was at 26\%, with only $31 \%$ of even those with high-risk conditions appropriately vaccinated (Flannery et al. 2017). This highlights the importance of efforts to increase overall influenza vaccination rates among children.

Although influenza vaccination is currently the most effective method of preventing seasonal influenza infection, vaccination has significant limitations in the pediatric population. IIV is not licensed for children less than 6 mo of age and is poorly immunogenic in young children, requiring a second booster dose with first vaccination. Adjuvants have been used to increase the effectiveness of IIV, with both MF59 and AS03 shown to increase immunogenicity through multiple mechanisms, including improved innate immune activation, B-cell reactivity, and CD4 T-cell recruitment (Zedda et al. 2015). Studies to date have shown the safety of MF59adjuvanted IIVs in children (Vesikari et al. 2018; Patel et al. 2019), with an MF59-adjuvanted seasonal trivalent influenza vaccine now approved for use in Canada. Although this increased immunogenicity offers great potential benefit, the association between an AS03-adjuvanted monovalent 2009 pandemic influenza vaccine and narcolepsy during the $2009 \mathrm{H} 1 \mathrm{~N} 1$ pandemic may have slowed more widespread adoption of these vaccines for use in children (Miller et al. 2013; Verstraeten et al. 2015; Sarkanen et al. 2018). 
J. Nayak et al.

In addition to poor immunogenicity, the lack of influenza vaccine licensure in infants less than 6 mo of age is particularly problematic as infants are at the highest risk for severe influenza infection with high hospitalization rates (Izurieta et al. 2000; Neuzil et al. 2000a). Pregnant and postpartum women are also at higher risk for severe influenza illness and complications; thus, it is recommended that all women who are or will be pregnant during the influenza season receive IIV as soon as it becomes available (Committee on Obstetric Practice 2018). Studies have shown that anti-influenza antibodies cross the placenta and result in higher hemagglutination inhibition (HAI) titers in cord blood compared with placebo recipients (Madhi et al. 2014), with lower rates of documented acute lower respiratory tract infection, influenza infections, and influenza-related hospitalizations in infants when mothers are vaccinated during pregnancy (Zaman et al. 2008; Benowitz et al. 2010; Nunes et al. 2017). Although vaccination at any point during pregnancy is recommended, infants had higher antibody titers against the $\mathrm{A}(\mathrm{H} 1 \mathrm{~N} 1)$ virus when vaccinated during the second or third trimester and $>4$ wk before delivery (Zhong et al. 2019). Vaccination of breastfeeding mothers with IIV as opposed to LAIV resulted in significantly higher serum HAI titers as well as IgG and IgA levels in breast milk, suggesting that IIV may also be the preferred vaccine in breastfeeding mothers (Brady et al. 2018).

Unlike IIV, LAIV is not recommended for children less than $2 \mathrm{yr}$ of age or during pregnancy. However, despite these limitations, LAIV may offer some advantages in the pediatric population. Early studies of LAIV, many of which were conducted before the U.S. recommendation for universal pediatric influenza vaccination, showed improved vaccine efficacy in children compared with IIV, including improved protection against antigenically drifted strains (Belshe et al. 2000a, 2007; Rhorer et al. 2009). Together, accumulated data ultimately led to the preferential recommendation for LAIV use in children in the 2014-2015 influenza season (Grohskopf et al. 2014). However, following replacement of the previously circu- lating $\mathrm{A}(\mathrm{H} 1 \mathrm{~N} 1)$ strain with the 2009 pandemic strain, data showing decreased protection against the 2009 pandemic vaccine component began to emerge (Chung et al. 2019). Multiple factors may have contributed to this poorer performance, with manufacturer evidence suggesting decreased replicative fitness of the A/California/7/2009 and the subsequent A/Bolivia/ $559 / 2013$ strains to be a primary contributor. For this reason, LAIV was not recommended for use in the United States in 2016-2017 and 2017-2018 (Grohskopf et al. 2016), but was again recommended in 2018-2019 with introduction of the A/Slovenia/2903/2015 H1N1 viral strain postulated to have greater shedding and immunogenicity (Grohskopf et al. 2018). However, it is of note that the U.S. findings of low effectiveness in the 2015-2016 season differed from findings in other countries, and other countries, including Canada, continued to recommend LAIV for children (Tam 2018). These data highlight the need for a better understanding of LAIV correlates of protection and the impact of preexisting immunity on vaccine effectiveness.

\section{PEDIATRIC HOST RESPONSE TO INFLUENZA INFECTION}

Immunity in infants differs both quantitatively and qualitatively from that in adults, with data interpretation further complicated by the presence of circulating maternal antibody. Most notably for influenza, production of Th17-associated effector cytokines on Toll-like receptor (TLR) signaling peaks postnatally in term infants and then declines over the first $2 \mathrm{yr}$ of age, whereas Th1-supporting cytokines, including IL-12p70 and IFN- $\gamma$, slowly increase throughout childhood (Yerkovich et al. 2007; Corbett et al. 2010). Early in life, there is also an elevated frequency of cells with a phenotype consistent with $\mathrm{T}_{\text {reg, }}$, with $10 \%-30 \%$ of $\mathrm{CD} 4$ T cells expressing CD25 and FOXP3 in the first $2 \mathrm{yr}$ of life (Thome et al. 2015). Further, the influenza-specific B- and T-cell repertoires in infants and young children contain a greater frequency of naive cells, with many fewer influenza-specific cells with a memory phenotype 
secondary to the limited influenza encounters through either annual vaccination or natural infection in this age group. This contrasts markedly with older children and adults, in which there are preexisting populations of influenza-specific memory cells that can target conserved epitopes (Kreijtz et al. 2007; Lee et al. 2008; Koutsakos et al. 2019) and provide nonsterilizing immunity on reinfection (McMichael et al. 1983; Wilkinson et al. 2012; Sridhar et al. 2013). Because the responding memory cells have a significant advantage in terms of both precursor frequency and the threshold of activation required to induce a response (Croft et al. 1994; London et al. 2000; Rogers et al. 2000; von Essen et al. 2012), the induction of an adaptive immune response in young children is likely delayed. This may contribute to higher levels of viral replication and age-dependent differences in susceptibility to influenza virus infection. These important immunologic differences underscore the need to evaluate immunity in infants without application of typical adult conventions, keeping in mind that the age on infection of a given child could substantially impact the nature of the ensuing immune response.

Following infection, influenza virus primarily targets and infects respiratory epithelial cells of children and adults via the viral hemagglutinin (HA) protein, and a vigorous inflammatory response ensues with activation of multiple pattern recognition receptors, including TLRs, the retinoic acid-inducible gene (RIG)-like receptors, and the nucleotide-binding oligomerization domain (NOD)-like receptors (Coates et al. 2015). This leads to a robust innate immune response with activation of neutrophils, monocyte recruitment, and maturation of dendritic cells, resulting in decreased viral replication and instruction of the developing adaptive immune response (Wu et al. 2011; Iwasaki and Pillai 2014; Pulendran and Maddur 2015). Following initial influenza infection of a child with no previous influenza exposures, naive influenza-specific CD4 T cells and CD8 T cells are activated and expand (Chen et al. 2018; Nüssing et al. 2018). In mouse models, lung tissue-resident memory CD8 $\mathrm{T}$ cells $\left(\mathrm{T}_{\mathrm{rm}}\right)$ established postinfection are poised to rapidly respond on reinfection and have a key role in immune protection (Wu et al. 2014; Pizzolla et al. 2017). These $\mathrm{T}_{\mathrm{rm}}$ cells are present in healthy adult lung tissue (Kumar et al. 2017; Pizzolla et al. 2018); however, when this population of cells is established following childhood influenza infection is not yet known. Interestingly, murine models suggest $\mathrm{T}_{\mathrm{rm}}$ may be less well-generated in infancy, providing another potential immunologic mechanism for the increased susceptibility of young children to influenza (Zens and Farber 2016).

Early infection with influenza virus also establishes a B-cell response, with a detectable memory B-cell response developing in children as young as 2 yr of age (Sasaki et al. 2007). On infection, B cells specific for a wide diversity of influenza viral proteins respond, with antibodies directed against epitopes to surface and internal proteins, including broadly protective epitopes within the HA stalk (He et al. 2015; Tesini et al. 2019). These cells persist and can be recalled on challenge with a divergent influenza strain (Wrammert et al. 2011; Margine et al. 2013). It has been well-established that on repeated exposure to closely related influenza strains epitopes within the HA head are immunodominant (Andrews et al. 2015; Lee et al. 2016); however, whether stalk reactive antibodies are relatively enriched for in the pediatric population has yet to be determined.

Although the preferential boosting of antibodies specific for earlier viral strains on encounter with an antigenically drifted influenza virus, or "original antigenic sin," was first described decades ago (Davenport et al. 1953; Francis 1960; Fazekas de St.Groth and Webster 1966), recent data has indicated that influenza strains originally encountered in childhood may establish long lasting protection against novel influenza strains belonging to the same HA group (Gostic et al. 2016). This cross-subtype protection has been termed "immunologic imprinting," and there is now an appreciation for its role in both establishing lasting anti-influenza protective immunity and in shaping lifelong responses to influenza vaccination (Reber et al. 2016; Nachbagauer et al. 2017; Nuñez et al. 2017; Kosikova et al. 2018). 
J. Nayak et al.

\section{MECHANISMS OF INFLUENZA VACCINE- ASSOCIATED PROTECTION FOLLOWING IIV}

IIV have been shown to be effective in both infants and young children (Jefferson et al. 2018), with protective antibody levels and the generation of antibody-secreting cells in even former premature infants vaccinated at 6-17 mo of age (Groothuis et al. 1992; D’Angio et al. 2011, 2017). This protection is predominately through stimulation of a HA-specific neutralizing antibody response quantified using the serum HAI antibody titer as a correlate of vaccine-induced protection. In adults, an HAI titer of $>1: 40$ is typically considered protective (de Jong et al. 2003; Treanor and Wright 2003; Ohmit et al. 2011), but higher HAI titers may be necessary to achieve similar levels of protection in children (Black et al. 2011).

In addition to B-cell responses, IIV induces CD4-T-cell responses even in very young children. When a population of IIV vaccinated children less than $3 \mathrm{yr}$ of age with no history of documented influenza infection was examined, influenza-reactive circulating CD4 T cell could be detected. Interestingly, the immunodominance hierarchy of this response reflected the composition of IIV, with detectable responses to the HA proteins but little reactivity to the internal virion proteins NP and M1 (Shannon et al. 2019). Vaccination is also able to activate a population of Tfh, with these cells detectable in the peripheral blood of older children. This shows the ability of childhood IIV vaccination to activate $\mathrm{Tfh}$ that then can provide cognate help to B cells (Bentebibel et al. 2013).

\section{MECHANISMS OF INFLUENZA VACCINATION FOLLOWING LAIV}

In contrast to IIV, the correlates of LAIVinduced immunological protection remain unclear, with traditional measurements of immunity failing to correlate with protection from subsequent LAIV challenge (Wright et al. 2016). Studies have established that the systemic neutralizing antibody titer is generally lower following immunization with LAIV as opposed to IIV
(Treanor et al. 1999; Sasaki et al. 2007; Nakaya et al. 2011; Ohmit et al. 2011; Cao et al. 2014), with higher LAIV-induced HAI titers associated with younger age and baseline seronegativity (Coelingh et al. 2014). Despite this modest serum HAI response, early studies of LAIV showed improved vaccine efficacy in children, including protection against antigenically drifted strains (Belshe et al. 2000a, 2007; Rhorer et al. 2009). Preferential induction of local as opposed to systemic immunity (Panapasa et al. 2015; Mohn et al. 2016; Jegaskanda et al. 2018), including mucosal antibody responses (Belshe et al. 2000b; Ambrose et al. 2012; Mohn et al. 2016), increased innate immune activation (Zhu et al. 2010; Nakaya et al. 2011), and more robust CD4 and CD8 T-cell responses (He et al. 2006; Hoft et al. 2011) may account for the effectiveness of LAIV in children despite lower HAI titers. Despite these potential advantages, the need for vaccine viruses to infect and undergo limited replication means that vaccine effectiveness may be impacted if preexisting host immunity neutralizes or curtails replication of vaccine virus (Ilyushina et al. 2015). This may account for the improved efficacy of LAIV in seronegative children as compared with adults and could potentially result in reduced immunogenicity in children vaccinated annually.

\section{RESEARCH GAPS}

Although great strides have recently been made in understanding the presentation, transmission, and immunity to influenza in children, exciting questions remain. Further research is needed to address how host and viral factors affect disease severity and predispose to secondary infections in infants and children. In addition, although it is thought that children are a primary driver of disease transmission, the mechanism by which host factors, such as smaller airway size and clinical features, impact transmission needs to be determined. Another area of emerging research is the mechanism underlying the greater durability of immunologic memory established following an early childhood infection. Many questions regarding the timing of imprinting, the impact of the developmental 
stage of the immune system, and the effects of maternal antibody at the time of an initial infection remain unanswered, as does the impact of imprinting on the early development of T-cellmediated immune memory. The effect of immunization with either IIV or LAIV before a first infection also remains undefined, as much of the data on imprinting are in adult cohorts first exposed to influenza via a natural infection. With universal influenza immunization, more children are first being exposed to this virus via inactivated and/or live attenuated vaccinations that establish preexisting immunity and may alter the ability of early infections to bias subsequent immune responses (Fig. 1). Further, a better understanding of the duration of protection that natural influenza infection provides, how this protects against infection with a drifted virus in children, and how the host immune response is subsequently remodeled on repeated
Influenza-naive infant

- Complex maternal antibody

- Naive CD4 and CD8 T-cell repertoire

- Developmentally immature immune system

- Circulating maternal Ab could impact immune response to infection

Influenza-naive toddler

- Naive influenza-specific CD4, CD8, and B cells

- Little or no preexisting circulating antibody

- Prolonged duration of viral antigen

Infant/toddler post-IIV immunization

- HA-focused CD4 T-cell and B-cell response

- Circulating HA antibody

- Developmental status of the immune system depends on age at time of infection

- Preexisting HA-specific Ab may limit infection/duration of antigen presentation

Toddler post-LAIV immunization

- Diverse memory CD4 and CD8 T-cell responses

- Diverse but limited abundance of B cells and circulating $\mathrm{Ab}$

Postinfection

- Diverse CD4 and CD8 T-cell responses

- Diverse B-cell response and circulating $A b$ response, including stalk-reactive $A b$

HA-specific B cells
Non-HA-specific B cells
HA-specific CD4 T cells
Non-HA-specific CD4 T cells
CD8 T cells
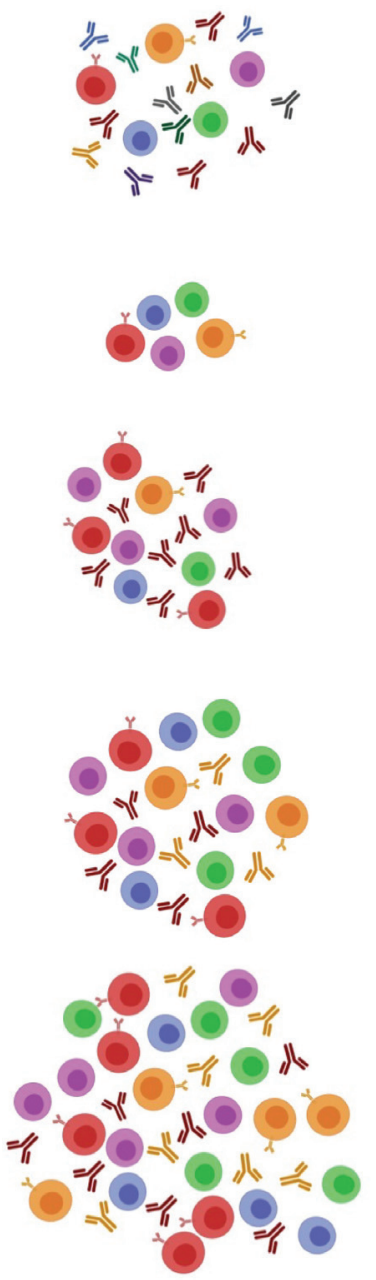

Figure 1. Impact of both the developmental stage of an infant's immune system and preexisting influenza-specific memory at the time of a first influenza infection. Different forms of prior antigenic exposure will impact the preexisting B- and T-cell repertoire, with development of influenza-specific immunity postinfection influenced by both the repertoire of available memory cells and the availability of antigen. 
J. Nayak et al.

influenza exposures is necessary. Understanding these issues is critical to defining how early immune history shapes lifelong anti-influenza immune memory.

\section{CONCLUSIONS}

Children are unique as they are relatively immunologically naive to influenza virus, leading to increased morbidity on infection. Further, the age and developmental status of the immune system on an initial exposure may contribute to unique manifestations of disease and have a substantial impact on the development of immunologic memory following infection or vaccination. Further research will need to more completely evaluate the development of anti-influenza immunity throughout childhood via the application of unbiased approaches to longitudinal cohorts to understand the complex interplay between the route and order of antigenic exposures, the developmental state of the immune system, and the environmental and genetic factors in shaping immunologic memory. Through a better understanding of how immunity develops during this critical window, insights into both early life priming and the complexity of the anti-influenza immune response will be gained, enabling development of longer lasting and more efficacious influenza vaccines that are effective across the human population.

\section{ACKNOWLEDGMENTS}

This article has been made freely available online courtesy of TAUNS Laboratories.

\section{REFERENCES}

Ali ST, Cowling BJ, Lau EHY, Fang VJ, Leung GM. 2018. Mitigation of influenza B epidemic with school closures, Hong Kong, 2018. Emerg Infect Dis 24: 2071-2073. doi:10 .3201/eid2411.180612

Ambrose CS, Antonova EN. 2014. The healthcare and societal burden associated with influenza in vaccinated and unvaccinated European and Israeli children. Eur J Clin Microbiol Infect Dis 33: 569-575. doi:10.1007/s10096013-1986-6

Ambrose CS, Levin MJ. 2012. The rationale for quadrivalent influenza vaccines. Hum Vaccin Immunother 8: 81-88. doi:10.4161/hv.8.1.17623
Ambrose CS, Wu X, Jones T, Mallory RM. 2012. The role of nasal IgA in children vaccinated with live attenuated influenza vaccine. Vaccine 30: 6794-6801. doi:10.1016/j .vaccine.2012.09.018

Andrews SF, Huang Y, Kaur K, Popova LI, Ho IY, Pauli NT, Henry Dunand CJ, Taylor WM, Lim S, Huang M, et al. 2015. Immune history profoundly affects broadly protective B cell responses to influenza. Sci Transl Med 7: 316ra192. doi:10.1126/scitranslmed.aad0522

Azman AS, Stark JH, Althouse BM, Vukotich CJ, Stebbins S, Burke DS, Cummings DAT. 2013. Household transmission of influenza A and B in a school-based study of nonpharmaceutical interventions. Epidemics 5: 181-186. https://doi.org/10.1016/j.epidem.2013.09.001

Baguelin M, Flasche S, Camacho A, Demiris N, Miller E, Edmunds WJ. 2013. Assessing optimal target populations for influenza vaccination programmes: an evidence synthesis and modelling study. PLoS Med 10: e1001527. doi:10.1371/journal.pmed.1001527

Bake B, Larsson P, Ljungkvist G, Ljungström E, Olin AC. 2019. Exhaled particles and small airways. Respir Res 20: 8. doi:10.1186/s12931-019-0970-9

Belshe RB, Gruber WC, Mendelman PM, Cho I, Reisinger K, Block SL, Wittes J, Iacuzio D, Piedra P, Treanor J, et al. 2000a. Efficacy of vaccination with live attenuated, coldadapted, trivalent, intranasal influenza virus vaccine against a variant (A/Sydney) not contained in the vaccine. $J$ Pediatr 136: 168-175. doi:10.1016/S0022-3476(00) 70097-7

Belshe RB, Gruber WC, Mendelman PM, Mehta HB, Mahmood K, Reisinger K, Treanor J, Zangwill K, Hayden FG, Bernstein DI, et al. 2000b. Correlates of immune protection induced by live, attenuated, cold-adapted, trivalent, intranasal influenza virus vaccine. J Infect Dis 181: 11331137. doi:10.1086/315323

Belshe RB, Edwards KM, Vesikari T, Black SV, Walker RE, Hultquist M, Kemble G, Connor EM, Group C-TCES. 2007. Live attenuated versus inactivated influenza vaccine in infants and young children. N Engl J Med 356: 685696. doi:10.1056/NEJMoa065368

Bennet R, Hamrin J, Wirgart BZ, Östlund MR, Örtqvist A, Eriksson M. 2016. Influenza epidemiology among hospitalized children in Stockholm, Sweden 1998-2014. Vaccine 34: 3298-3302. doi:10.1016/j.vaccine.2016.04.082

Benowitz I, Esposito DB, Gracey KD, Shapiro ED, Vázquez M. 2010. Influenza vaccine given to pregnant women reduces hospitalization due to influenza in their infants. Clin Infect Dis 51: 1355-1361. doi:10.1086/657309

Bentebibel SE, Lopez S, Obermoser G, Schmitt N, Mueller C, Harrod C, Flano E, Mejias A, Albrecht RA, Blankenship $\mathrm{D}$, et al. 2013. Induction of $\mathrm{ICOS}^{+} \mathrm{CXCR}^{+} \mathrm{CXCR}^{+} \mathrm{T}_{\mathrm{H}}$ cells correlates with antibody responses to influenza vaccination. Sci Transl Med 5: 176ra132. doi:10.1126/sci translmed.3005191

Black S, Nicolay U, Vesikari T, Knuf M, Del Giudice G, Della Cioppa G, Tsai T, Clemens R, Rappuoli R. 2011. Hemagglutination inhibition antibody titers as a correlate of protection for inactivated influenza vaccines in children. Pediatr Infect Dis J 30: 1081-1085. doi:10.1097/INF .0b013e3182367662

Brady RC, Jackson LA, Frey SE, Shane AL, Walter EB, Swamy GK, Schlaudecker EP, Szefer E, Wolff M, McNeal 
MM, et al. 2018. Randomized trial comparing the safety and antibody responses to live attenuated versus inactivated influenza vaccine when administered to breastfeeding women. Vaccine 36: 4663-4671. doi:10.1016/j.vaccine .2018 .06 .036

Britton PN, Blyth CC, Macartney K, Dale RC, Li-Kim-Moy J, Khandaker G, Crawford NW, Marshall H, Clark JE, Elliott EJ, et al. 2017. The spectrum and burden of influenza-associated neurological disease in children: combined encephalitis and influenza sentinel site surveillance from Australia, 2013-2015. Clin Infect Dis 65: 653-660. doi:10 $1093 / \mathrm{cid} / \mathrm{cix} 412$

Caini S, Spreeuwenberg P, Kusznierz GF, Rudi JM, Owen R, Pennington K, Wangchuk S, Gyeltshen S, Ferreira de Almeida WA, Pessanha Henriques CM, et al. 2018. Distribution of influenza virus types by age using case-based global surveillance data from twenty-nine countries, 1999-2014. BMC Infect Dis 18: 269. doi:10.1186/ s12879-018-3181-y

Calitri C, Gabiano C, Garazzino S, Pinon M, Zoppo M, Cuozzo M, Scolfaro C, Tovo PA. 2010. Clinical features of hospitalised children with 2009 H1N1 influenza virus infection. Eur J Pediatr 169: 1511-1515. doi:10.1007/ s00431-010-1255-y

Cao RG, Suarez NM, Obermoser G, Lopez SM, Flano E, Mertz SE, Albrecht RA, García-Sastre A, Mejias A, Xu $\mathrm{H}$, et al. 2014. Differences in antibody responses between trivalent inactivated influenza vaccine and live attenuated influenza vaccine correlate with the kinetics and magnitude of interferon signaling in children. J Infect Dis 210: 224-233. doi:10.1093/infdis/jiu079

Casado I, Martínez-Baz I, Burgui R, Irisarri F, Arriazu M, Elía F, Navascués A, Ezpeleta C, Aldaz P, Castilla J, et al 2014. Household transmission of influenza A(H1N1) pdm09 in the pandemic and post-pandemic seasons. PLoS ONE 9: e108485. doi:10.1371/journal.pone.0108485

Cauchemez S, Valleron AJ, Boëlle PY, Flahault A, Ferguson NM. 2008. Estimating the impact of school closure on influenza transmission from Sentinel data. Nature 452 750-754. doi:10.1038/nature06732

Cauchemez S, Donnelly CA, Reed C, Ghani AC, Fraser C, Kent CK, Finelli L, Ferguson NM. 2009. Household transmission of 2009 pandemic influenza A (H1N1) virus in the United States. N Engl J Med 361: 2619-2627. doi:10 .1056/NEJMoa0905498.

Centers for Disease Control and Prevention. 2019. Past seasons' vaccine effectiveness estimates. Centers for Disease Control and Prevention, National Center for Immunization and Respiratory Diseases (NCIRD). https://www.cdc .gov/flu/vaccines-work/past-seasons-estimates.html (updated on 4/5/2019)

Chapman J, Arnold J. 2019. Reye syndrome. StatPearls, Treasure Island, FL.

Chen X, Liu S, Goraya MU, Maarouf M, Huang S, Chen JL. 2018. Host immune response to influenza A virus infection. Front Immunol 9: 320. doi:10.3389/fimmu.2018 .00320

Chung JR, Flannery B, Ambrose CS, Bégué RE, Caspard H, DeMarcus L, Fowlkes AL, Kersellius G, Steffens A, Fry AM, et al. 2019. Live attenuated and inactivated influenza vaccine effectiveness. Pediatrics 143: e20182094. doi:10 $.1542 /$ peds.2018-2094
Coates BM, Staricha KL, Wiese KM, Ridge KM. 2015. Influenza A virus infection, innate immunity, and childhood. JAMA Pediatr 169: 956-963. doi:10.1001/jamapediatrics .2015 .1387

Coelingh KL, Wu XW, Mallory RM, Ambrose CS. 2014. An integrated multi-study analysis of serum HAI antibody responses to Ann Arbor strain live attenuated influenza vaccine in children and adults. Trials Vaccinol 3: 150-153. doi:10.1016/j.trivac.2014.08.001

Committee on Obstetric Practice. 2018. ACOG Committee Opinion No. 732: Influenza vaccination during pregnancy. Obstet Gynecol 131: e109-e114. doi:10.1097/AOG .0000000000002588

Corbett NP, Blimkie D, Ho KC, Cai B, Sutherland DP, Kallos A, Crabtree J, Rein-Weston A, Lavoie PM, Turvey SE, et al. 2010. Ontogeny of Toll-like receptor mediated cytokine responses of human blood mononuclear cells. PLoS ONE 5: e15041. doi:10.1371/journal.pone.0015041

Croft M, Bradley LM, Swain SL. 1994. Naive versus memory CD4 T cell response to antigen. Memory cells are less dependent on accessory cell costimulation and can respond to many antigen-presenting cell types including resting B cells. J Immunol 152: 2675-2685.

D’Angio CT, Heyne RJ, Duara S, Holmes LC, O'Shea TM, Wang H, Wang D, Sánchez PJ, Welliver RC, Ryan RM, et al. 2011. Immunogenicity of trivalent influenza vaccine in extremely low-birth-weight, premature versus term infants. Pediatr Infect Dis J 30: 570-574. doi:10.1097/INF .0b013e31820c1fdf

D'Angio CT, Wyman CP, Misra RS, Halliley JL, Wang H, Hunn JE, Fallone CM, Lee FE. 2017. Plasma cell and serum antibody responses to influenza vaccine in preterm and full-term infants. Vaccine 35: 5163-5171. doi:10 $.1016 /$ j.vaccine.2017.07.115

Davenport FM, Hennessy AV, Francis T Jr. 1953. Epidemiologic and immunologic significance of age distribution of antibody to antigenic variants of influenza virus. J Exp Med 98: 641-656. doi:10.1084/jem.98.6.641

de Jong JC, Palache AM, Beyer WE, Rimmelzwaan GF, Boon AC, Osterhaus AD. 2003. Haemagglutination-inhibiting antibody to influenza virus. Dev Biol (Basel) 115: 63-73.

Dodds L, McNeil SA, Fell DB, Allen VM, Coombs A, Scott J, MacDonald N. 2007. Impact of influenza exposure on rates of hospital admissions and physician visits because of respiratory illness among pregnant women. $C M A J 176$ : 463-468. doi:10.1503/cmaj.061435

Fazekas de St.Groth S, Webster RG. 1966. Disquisitions of original antigenic sin. I. Evidence in man. J Exp Med 124: 331-345. doi:10.1084/jem.124.3.331

Flannery B, Reynolds SB, Blanton L, Santibanez TA, O’Halloran A, Lu PJ, Chen J, Foppa IM, Gargiullo P, Bresee J, et al. 2017. Influenza vaccine effectiveness against pediatric deaths: 2010-2014. Pediatrics 139: e20164244. doi:10 $.1542 /$ peds.2016-4244

Fowlkes A, Giorgi A, Erdman D, Temte J, Goodin K, Di Lonardo S, Sun Y, Martin K, Feist M, Linz R, et al. 2014. Viruses associated with acute respiratory infections and influenza-like illness among outpatients from the Influenza Incidence Surveillance Project, 2010-2011. J Infect Dis 209: 1715-1725. doi:10.1093/infdis/jit806

Francis T Jr. 1960. On the doctrine of original antigenic sin. Proc Am Philos Soc 104: 572-578. 
J. Nayak et al.

Frank AL, Taber LH, Wells CR, Wells JM, Glezen WP, Paredes A. 1981. Patterns of shedding of myxoviruses and paramyxoviruses in children. J Infect Dis 144: 433-441. doi:10.1093/infdis/144.5.433

Friedman MJ, Attia MW. 2004. Clinical predictors of influenza in children. Arch Pediatr Adolesc Med 158: 391-394. doi:10.1001/archpedi.158.4.391

Gordon A, Reingold A. 2018. The burden of influenza: a complex problem. Curr Epidemiol Rep 5: 1-9. doi:10 .1007/s40471-018-0136-1

Gordon A, Tsang TK, Cowling BJ, Kuan G, Ojeda S, Sanchez N, Gresh L, Lopez R, Balmaseda A, Harris E. 2018. Influenza transmission dynamics in urban households, Managua, Nicaragua, 2012-2014. Emerg Infect Dis 24: 1882-1888. doi:10.3201/eid2410.161258

Gostic KM, Ambrose M, Worobey M, Lloyd-Smith JO. 2016. Potent protection against H5N1 and H7N9 influenza via childhood hemagglutinin imprinting. Science 354: 722 726. doi:10.1126/science.aag1322

Gresh L, Kuan G, Sanchez N, Azziz-Baumgartner E, Ojeda S, Melendez M, Lopez R, Martin ET, Widdowson MA, Bresee J, et al. 2016. Burden of influenza and influenza-associated pneumonia in the first year of life in a prospective cohort study in Managua, Nicaragua. Pediatr Infect Dis J 35: 152-156. doi:10.1097/INF.0000000000000944

Grohskopf LA, Olsen SJ, Sokolow LZ, Bresee JS, Cox NJ, Broder KR, Karron RA, Walter EB, Centers for Disease C, Prevention. 2014. Prevention and control of seasonal influenza with vaccines: recommendations of the Advisory Committee on Immunization Practices (ACIP) United States, 2014-15 influenza season. MMWR Morb Mortal Wkly Rep 63: 691-697.

Grohskopf LA, Sokolow LZ, Broder KR, Olsen SJ, Karron RA, Jernigan DB, Bresee JS. 2016. Prevention and control of seasonal influenza with vaccines. MMWR Recomm Rep 65: 1-54. doi:10.15585/mmwr.rr6505al

Grohskopf LA, Sokolow LZ, Broder KR, Walter EB, Fry AM, Jernigan DB. 2018. Prevention and control of seasonal influenza with vaccines: recommendations of the advisory committee on immunization practices-United States, 2018-19 influenza season. MMWR Recomm Rep 67: 120. doi:10.15585/mmwr.rr6703a1

Grohskopf LA, Alyanak E, Broder KR, Walter EB, Fry AM, Jernigan DB. 2019. Prevention and control of seasonal influenza with vaccines: recommendations of the Advisory Committee on Immunization Practices-United States, 2019-20 influenza season. MMWR Recomm Rep 68: 1-21. doi:10.15585/mmwr.rr6803a1

Groothuis JR, Levin MJ, Lehr MV, Weston JA, Hayward AR. 1992. Immune response to split-product influenza vaccine in preterm and full-term young children. Vaccine 10: 221-225. doi:10.1016/0264-410X(92)90156-E

He XS, Holmes TH, Zhang C, Mahmood K, Kemble GW, Lewis DB, Dekker CL, Greenberg HB, Arvin AM. 2006. Cellular immune responses in children and adults receiving inactivated or live attenuated influenza vaccines. $J$ Virol 80: 11756-11766. doi:10.1128/JVI.01460-06

He XS, Holmes TH, Sanyal M, Albrecht RA, García-Sastre A, Dekker CL, Davis MM, Greenberg HB. 2015. Distinct patterns of B-cell activation and priming by natural in fluenza virus infection versus inactivated influenza vacci- nation. J Infect Dis 211: 1051-1059. doi:10.1093/infdis/ jiu580

Hoft DF, Babusis E, Worku S, Spencer CT, Lottenbach K, Truscott SM, Abate G, Sakala IG, Edwards KM, Creech $\mathrm{CB}$, et al. 2011. Live and inactivated influenza vaccines induce similar humoral responses, but only live vaccines induce diverse T-cell responses in young children. J Infect Dis 204: 845-853. doi:10.1093/infdis/jir436

Ilyushina NA, Haynes BC, Hoen AG, Khalenkov AM, Housman ML, Brown EP, Ackerman ME, Treanor JJ, Luke CJ, Subbarao K, et al. 2015. Live attenuated and inactivated influenza vaccines in children. J Infect Dis 211: 352-360. doi:10.1093/infdis/jiu458

Irving SA, Patel DC, Kieke BA, Donahue JG, Vandermause MF, Shay DK, Belongia EA. 2012. Comparison of clinical features and outcomes of medically attended influenza A and influenza $B$ in a defined population over four seasons: 2004-2005 through 2007-2008. Influenza Other Respir Viruses 6: 37-43. doi:10.1111/j.1750-2659.2011.00263.x

Iwasaki A, Pillai PS. 2014. Innate immunity to influenza virus infection. Nat Rev Immunol 14: 315-328. doi:10 .1038/nri3665

Izurieta HS, Thompson WW, Kramarz P, Shay DK, Davis RL, DeStefano F, Black S, Shinefield H, Fukuda K. 2000. Influenza and the rates of hospitalization for respiratory disease among infants and young children. $N$ Engl $J$ Med 342: 232-239. doi:10.1056/NEJM200001273420402

Jackson C, Vynnycky E, Hawker J, Olowokure B, Mangtani P. 2013. School closures and influenza: systematic review of epidemiological studies. BMJ Open 3: e002149. doi:10 $.1136 /$ bmjopen-2012-002149

Jefferson T, Rivetti A, Di Pietrantonj C, Demicheli V. 2018. Vaccines for preventing influenza in healthy children. Cochrane Database Syst Rev 2: CD004879. doi:10.1002/ 14651858.CD004879.pub5

Jegaskanda S, Mason RD, Andrews SF, Wheatley AK, Zhang R, Reynoso GV, Ambrozak DR, Santos CP, Luke CJ, Matsuoka $\mathrm{Y}$, et al. 2018. Intranasal live influenza vaccine priming elicits localized $\mathrm{B}$ cell responses in mediastinal lymph nodes. J Virol 92: e01970-17. doi:10.1128/JVI .01970-17

Jernigan DB, Cox NJ. 2013. Human influenza: one health, one world. In Textbook of influenza (ed. Webster RG, Monto AS, et al.), pp. 1-19. John Wiley, Hoboken, NJ.

Kasai T, Togashi T, Morishima T. 2000. Encephalopathy associated with influenza epidemics. Lancet 355: 1558 1559. doi:10.1016/S0140-6736(05)74614-6

Kosikova M, Li L, Radvak P, Ye Z, Wan XF, Xie H. 2018. Imprinting of repeated influenza A/H3 exposures on antibody quantity and antibody quality: implications on seasonal vaccine strain selection and vaccine performance. Clin Infect Dis 67: 1523-1532. doi:10.1093/cid/ ciy327

Koutsakos M, Illing PT, Nguyen THO, Mifsud NA, Crawford JC, Rizzetto S, Eltahla AA, Clemens EB, Sant S, Chua BY, et al. 2019. Human $\mathrm{CD}^{+} \mathrm{T}$ cell cross-reactivity across influenza A, B and C viruses. Nat Immunol 20: 613-625. doi:10.1038/s41590-019-0320-6

Kreijtz JH, Bodewes R, van Amerongen G, Kuiken T, Fouchier RA, Osterhaus AD, Rimmelzwaan GF. 2007. Primary influenza A virus infection induces cross-protective immunity against a lethal infection with a heterosubtypic 
virus strain in mice. Vaccine 25: 612-620. doi:10.1016/j .vaccine.2006.08.036

Kumar BV, Ma W, Miron M, Granot T, Guyer RS, Carpenter DJ, Senda T, Sun X, Ho SH, Lerner H, et al. 2017. Human tissue-resident memory $\mathrm{T}$ cells are defined by core transcriptional and functional signatures in lymphoid and mucosal sites. Cell Rep 20: 2921-2934. doi:10.1016/j .celrep.2017.08.078

Lee LY, Ha do LA, Simmons C, de Jong MD, Chau NV, Schumacher R, Peng YC, McMichael AJ, Farrar JJ, Smith GL, et al. 2008. Memory T cells established by seasonal human influenza A infection cross-react with avian influenza A (H5N1) in healthy individuals. J Clin Invest 118: 3478-3490. doi:10.1172/JCI32460

Lee J, Boutz DR, Chromikova V, Joyce MG, Vollmers C Leung K, Horton AP, DeKosky BJ, Lee CH, Lavinder JJ, et al. 2016. Molecular-level analysis of the serum antibody repertoire in young adults before and after seasonal influenza vaccination. Nat Med 22: 1456-1464. doi:10.1038/ nm. 4224

London CA, Lodge MP, Abbas AK. 2000. Functional responses and costimulator dependence of memory $\mathrm{CD} 4^{+}$ T cells. J Immunol 164: 265-272. doi:10.4049/jimmunol .164 .1 .265

Madhi SA, Cutland CL, Kuwanda L, Weinberg A, Hugo A Jones S, Adrian PV, van Niekerk N, Treurnicht F, Ortiz $J R$, et al. 2014. Influenza vaccination of pregnant women and protection of their infants. N Engl J Med 371: 918931. doi:10.1056/NEJMoa1401480

Maier HE, Lopez R, Sanchez N, Ng S, Gresh L, Ojeda S, Burger-Calderon R, Kuan G, Harris E, Balmaseda A, et al. 2018. Obesity increases the duration of influenza $A$ virus shedding in adults. $J$ Infect Dis 218: 1378-1382. doi:10.1093/infdis/jiy370

Margine I, Hai R, Albrecht RA, Obermoser G, Harrod AC, Banchereau J, Palucka K, García-Sastre A, Palese P, Treanor JJ, et al. 2013. H3N2 influenza virus infection induces broadly reactive hemagglutinin stalk antibodies in humans and mice. J Virol 87: 4728-4737. doi:10.1128/JVI .03509-12

McLean HQ, Peterson SH, King JP, Meece JK, Belongia EA. 2017. School absenteeism among school-aged children with medically attended acute viral respiratory illness during three influenza seasons, 2012-2013 through 2014-2015. Influenza Other Respir Viruses 11: 220-229. doi:10.1111/irv.12440

McMichael AJ, Gotch FM, Noble GR, Beare PA. 1983. Cytotoxic T-cell immunity to influenza. N Engl J Med 309: 13-17. doi:10.1056/NEJM198307073090103

Miller E, Andrews N, Stellitano L, Stowe J, Winstone AM, Shneerson J, Verity C. 2013. Risk of narcolepsy in children and young people receiving AS03 adjuvanted pandemic A/H1N1 2009 influenza vaccine: retrospective analysis. BMJ 346: f794. doi:10.1136/bmj.f794

Milton DK, Fabian MP, Cowling BJ, Grantham ML, McDevitt JJ. 2013. Influenza virus aerosols in human exhaled breath: particle size, culturability, and effect of surgical masks. PLoS Pathog 9: e1003205. doi:10.1371/journal .ppat.1003205

Minodier L, Charrel RN, Ceccaldi PE, van der Werf S, Blanchon T, Hanslik T, Falchi A. 2015. Prevalence of gastrointestinal symptoms in patients with influenza, clinical significance, and pathophysiology of human influenza viruses in faecal samples: what do we know? Virol J 12: 215-215. doi:10.1186/s12985-015-0448-4

Mohn KG, Brokstad KA, Pathirana RD, Bredholt G, JulLarsen A, Trieu MC, Lartey SL, Montomoli E, Tøndel C, Aarstad HJ, et al. 2016. Live attenuated influenza vaccine in children induces B-cell responses in tonsils. J Infect Dis 214: 722-731. doi:10.1093/infdis/jiw230

Monto AS. 1999. Interrupting the transmission of respiratory tract infections: theory and practice. Clin Infect Dis 28: 200-204. doi:10.1086/515113

Monto AS, Kioumehr F. 1975. The Tecumseh Study of respiratory illness. IX: occurrence of influenza in the community, 1966-1971. Am J Epidemiol 102: 553-563. doi:10 .1093/oxfordjournals.aje.a112193

Monto AS, Gravenstein S, Elliott M, Colopy M, Schweinle J. 2000. Clinical signs and symptoms predicting influenza infection. Arch Intern Med 160: 3243-3247. doi:10.1001/ archinte.160.21.3243

Mossong J, Hens N, Jit M, Beutels P, Auranen K, Mikolajczyk R, Massari M, Salmaso S, Tomba GS, Wallinga J, et al. 2008. Social contacts and mixing patterns relevant to the spread of infectious diseases. PLoS Med 5: e74. doi:10 .1371/journal.pmed.0050074

Nachbagauer R, Choi A, Hirsh A, Margine I, Iida S, Barrera A, Ferres M, Albrecht RA, García-Sastre A, Bouvier NM, et al. 2017. Defining the antibody cross-reactome directed against the influenza virus surface glycoproteins. Nat Immunol 18: 464-473. doi:10.1038/ni.3684

Nair H, Brooks WA, Katz M, Roca A, Berkley JA, Madhi SA, Simmerman JM, Gordon A, Sato M, Howie S, et al. 2011. Global burden of respiratory infections due to seasonal influenza in young children: a systematic review and meta-analysis. Lancet 378: 1917-1930. doi:10.1016/ S0140-6736(11)61051-9

Nakaya HI, Wrammert J, Lee EK, Racioppi L, Marie-Kunze S, Haining WN, Means AR, Kasturi SP, Khan N, Li GM, et al. 2011. Systems biology of vaccination for seasonal influenza in humans. Nat Immunol 12: 786-795. doi:10 $.1038 /$ ni.2067

Neuzil KM, Mellen BG, Wright PF, Mitchel EF, Griffin MR. 2000a. The effect of influenza on hospitalizations, outpatient visits, and courses of antibiotics in children. $N$ Engl $J$ Med 342: 225-231. doi:10.1056/NEJM200001273420401

Neuzil KM, Wright PF, Mitchel EF Jr, Griffin MR. 2000b. The burden of influenza illness in children with asthma and other chronic medical conditions. J Pediatr 137: 856864. doi:10.1067/mpd.2000.110445

Neuzil KM, Zhu Y, Griffin MR, Edwards KM, Thompson JM, Tollefson SJ, Wright PF. 2002. Burden of interpandemic influenza in children younger than 5 years: a 25-year prospective study. J Infect Dis 185: 147-152. doi: $10.1086 / 338363$

Ng S, Lopez R, Kuan G, Gresh L, Balmaseda A, Harris E, Gordon A. 2016. The timeline of influenza virus shedding in children and adults in a household transmission study of influenza in Managua, Nicaragua. Pediatr Infect Dis J 35: 583-586. doi:10.1097/INF.0000000000001083

Nunes MC, Cutland CL, Jones S, Downs S, Weinberg A, Ortiz JR, Neuzil KM, Simões EAF, Klugman KP, Madhi SA. 2017. Efficacy of maternal influenza vaccination against all-cause lower respiratory tract infection hospi- 
J. Nayak et al.

talizations in young infants: results from a randomized controlled trial. Clin Infect Dis 65: 1066-1071. doi:10 $.1093 / \mathrm{cid} / \mathrm{cix} 497$

Nuñez IA, Carlock MA, Allen JD, Owino SO, Moehling KK, Nowalk P, Susick M, Diagle K, Sweeney K, Mundle S, et al. 2017. Impact of age and pre-existing influenza immune responses in humans receiving split inactivated influenza vaccine on the induction of the breadth of antibodies to influenza A strains. PLoS ONE 12: e0185666. doi:10.1371/ journal.pone.0185666

Nüssing S, Sant S, Koutsakos M, Subbarao K, Nguyen THO, Kedzierska K. 2018. Innate and adaptive T cells in influenza disease. Front Med 12: 34-47. doi:10.1007/s11684017-0606-8

Ohmit SE, Petrie JG, Cross RT, Johnson E, Monto AS. 2011 Influenza hemagglutination-inhibition antibody titer as a correlate of vaccine-induced protection. J Infect Dis 204: 1879-1885. doi:10.1093/infdis/jir661

Omer SB, Goodman D, Steinhoff MC, Rochat R, Klugman KP, Stoll BJ, Ramakrishnan U. 2011. Maternal influenza immunization and reduced likelihood of prematurity and small for gestational age births: a retrospective cohort study. PLoS Med 8: e1000441. doi:10.1371/journal.pmed .1000441

Panapasa JA, Cox RJ, Mohn KG, Aqrawi LA, Brokstad KA. 2015. The expression of B \& T cell activation markers in children's tonsils following live attenuated influenza vaccine. Hum Vaccin Immunother 11: 1663-1672. doi:10 $.1080 / 21645515.2015 .1032486$

Patel SS, Bizjajeva S, Heijnen E, Oberye J. 2019. MF59-adjuvanted seasonal trivalent inactivated influenza vaccine: safety and immunogenicity in young children at risk of influenza complications. Int J Infect Dis 85: S18-S25. doi:10.1016/j.ijid.2019.04.023

Paul Glezen W, Schmier JK, Kuehn CM, Ryan KJ, Oxford J. 2013. The burden of influenza B: a structured literature review. Am J Public Health 103: e43-e51. doi:10.2105/ AJPH.2012.301137

Pebody RG, Green HK, Andrews N, Boddington NL, Zhao $\mathrm{H}$, Yonova I, Ellis J, Steinberger S, Donati M, Elliot AJ, et al. 2015. Uptake and impact of vaccinating school age children against influenza during a season with circulation of drifted influenza A and B strains, England, 2014/ 15. Euro Surveill 20: 30029. doi:10.2807/1560-7917.ES 2015.20.39.30029

Pizzolla A, Nguyen THO, Smith JM, Brooks AG, Kedzierska K, Heath WR, Reading PC, Wakim LM. 2017. Resident memory $\mathrm{CD} 8^{+} \mathrm{T}$ cells in the upper respiratory tract prevent pulmonary influenza virus infection. Sci Immunol 2: eaam6970. doi:10.1126/sciimmunol.aam6970

Pizzolla A, Nguyen THO, Sant S, Jaffar J, Loudovaris T, Mannering SI, Thomas PG, Westall GP, Kedzierska K, Wakim LM. 2018. Influenza-specific lung-resident memory $\mathrm{T}$ cells are proliferative and polyfunctional and maintain diverse TCR profiles. J Clin Invest 128: 721-733. doi:10.1172/JCI96957

Poehling KA, Edwards KM, Weinberg GA, Szilagyi P, Staat MA, Iwane MK, Bridges CB, Grijalva CG, Zhu Y, Bernstein DI, et al. 2006. The underrecognized burden of influenza in young children. $N$ Engl J Med 355: 31-40. doi:10.1056/NEJMoa054869
Principi N, Esposito S, Marchisio P, Gasparini R, Crovari P. 2003. Socioeconomic impact of influenza on healthy children and their families. Pediatr Infect Dis J 22: S207-S210. doi:10.1097/01.inf.0000092188.48726.e4

Pulendran B, Maddur MS. 2015. Innate immune sensing and response to influenza. Curr Top Microbiol Immunol 386: 23-71.

Reber AJ, Kim JH, Coleman LA, Spencer SM, Chung JR, Chen J, Gargiullo P, Sundaram ME, Belongia EA, Shay $\mathrm{DK}$, et al. 2016. Seasonal influenza vaccination of children induces humoral and cell-mediated immunity beyond the current season: cross-reactivity with past and future strains. J Infect Dis 214: 1477-1486. doi:10.1093/infdis/ jiw380

Rhorer J, Ambrose CS, Dickinson S, Hamilton H, Oleka NA, Malinoski FJ, Wittes J. 2009. Efficacy of live attenuated influenza vaccine in children: a meta-analysis of nine randomized clinical trials. Vaccine 27: 1101-1110. doi:10 $.1016 /$ j.vaccine. 2008.11 .093

Rogers PR, Dubey C, Swain SL. 2000. Qualitative changes accompany memory $\mathrm{T}$ cell generation: faster, more effective responses at lower doses of antigen. J Immunol 164: 2338-2346. doi:10.4049/jimmunol.164.5.2338

Ruf BR, Knuf M. 2014. The burden of seasonal and pandemic influenza in infants and children. Eur J Pediatr 173 265-276. doi:10.1007/s00431-013-2023-6

Russell CA, Jones TC, Barr IG, Cox NJ, Garten RJ, Gregory V, Gust ID, Hampson AW, Hay AJ, Hurt AC, et al. 2008 The global circulation of seasonal influenza A (H3N2) viruses. Science 320: 340-346. doi:10.1126/science .1154137

Sarkanen TO, Alakuijala APE, Dauvilliers YA, Partinen MM. 2018. Incidence of narcolepsy after H1N1 influenza and vaccinations: systematic review and meta-analysis. Sleep Med Rev 38: 177-186. doi:10.1016/j.smrv.2017.06 .006

Sasaki S, Jaimes MC, Holmes TH, Dekker CL, Mahmood K, Kemble GW, Arvin AM, Greenberg HB. 2007. Comparison of the influenza virus-specific effector and memory B-cell responses to immunization of children and adults with live attenuated or inactivated influenza virus vaccines. J Virol 81: 215-228. doi:10.1128/JVI.01957-06

Schwarz K, Biller H, Windt H, Koch W, Hohlfeld JM. 2010. Characterization of exhaled particles from the healthy human lung-a systematic analysis in relation to pulmonary function variables. J Aerosol Med Pulm Drug Deliv 23: 371-379. doi:10.1089/jamp.2009.0809

Sellers SA, Hagan RS, Hayden FG, Fischer WA II. 2017. The hidden burden of influenza: a review of the extra-pulmonary complications of influenza infection. Influenza Other Respir Viruses 11: 372-393. doi:10.1111/irv.12470

Shang M, Blanton L, Brammer L, Olsen SJ, Fry AM. 2018. Influenza-associated pediatric deaths in the United States, 2010-2016. Pediatrics 141: e20172918. doi:10.1542/peds .2017-2918

Shannon I, White CL, Murphy A, Qiu X, Treanor JJ, Nayak JL. 2019. Differences in the influenza-specific CD4 T cell immunodominance hierarchy and functional potential between children and young adults. Sci Rep 9: 791. doi:10.1038/s41598-018-37167-5

Silvennoinen H, Peltola V, Lehtinen P, Vainionpää R, Heikkinen T. 2009. Clinical presentation of influenza in unse- 
lected children treated as outpatients. Pediatr Infect Dis $J$ 28: 372-375. doi:10.1097/INF.0b013e318191eef7

Silvennoinen $\mathrm{H}$, Huusko T, Vuorinen T, Heikkinen T. 2015. Comparative burden of influenza $\mathrm{A} / \mathrm{H} 1 \mathrm{~N} 1, \mathrm{~A} /$ $\mathrm{H} 3 \mathrm{~N} 2$ and $\mathrm{B}$ infections in children treated as outpatients. Pediatr Infect Dis J 34: 1081-1085. doi:10.1097/INF .0000000000000814

Sridhar S, Begom S, Bermingham A, Hoschler K, Adamson W, Carman W, Bean T, Barclay W, Deeks JJ, Lalvani A. 2013. Cellular immune correlates of protection against symptomatic pandemic influenza. Nat Med 19: 13051312. doi: $10.1038 / \mathrm{nm} .3350$

Tam TWS. 2018. Intranasal influenza vaccine: why does Canada have different recommendations from the USA on its use? Paediatr Child Health 23: 31-34. doi:10.1093/ pch/pxx195

Tesini BL, Kanagaiah P, Wang J, Hahn M, Halliley JL, Chaves FA, Nguyen PQT, Nogales A, DeDiego ML, Anderson CS, et al. 2019. Broad hemagglutinin-specific memory B cell expansion by seasonal influenza virus infection reflects early-life imprinting and adaptation to the infecting virus. J Virol 93: e00169-19. doi:10.1128/JVI .00169-19

Thome JJC, Bickham KL, Ohmura Y, Kubota M, Matsuoka N, Gordon C, Granot T, Griesemer A, Lerner H, Kato T, et al. 2015. Early-life compartmentalization of human T cell differentiation and regulatory function in mucosal and lymphoid tissues. Nat Med 22: 72-77. doi:10.1038/nm .4008

Thompson MG, Levine MZ, Bino S, Hunt DR, Al-Sanouri TM, Simões EAF, Porter RM, Biggs HM, Gresh L, Simaku A, et al. 2019. Underdetection of laboratory-confirmed influenza-associated hospital admissions among infants: a multicentre, prospective study. Lancet Child Adolesc Health 3: 781-794. doi:10.1016/S2352-4642(19) 30246-9

Treanor J, Wright PF. 2003. Immune correlates of protection against influenza in the human challenge model. Dev Biol (Basel) 115: 97-104.

Treanor JJ, Kotloff K, Betts RF, Belshe R, Newman F, Iacuzio D, Wittes J, Bryant M. 1999. Evaluation of trivalent, live, cold-adapted (CAIV-T) and inactivated (TIV) influenza vaccines in prevention of virus infection and illness following challenge of adults with wild-type influenza A (H1N1), A (H3N2), and B viruses. Vaccine 18: 899906. doi:10.1016/S0264-410X(99)00334-5

Troeger CE, Blacker BF, Khalil IA, Zimsen SRM, Albertson SB., Abate D, Abdela J, Adhikari TB, Aghayan SA, Agrawal S, et al. 2019. Mortality, morbidity, and hospitalisations due to influenza lower respiratory tract infections, 2017: an analysis for the Global Burden of Disease Study 2017. Lancet Respir Med 7: 69-89. doi:10.1016/S22132600(18)30496-X

Tsang TK, Cowling BJ, Fang VJ, Chan KH, Ip DK, Leung GM, Peiris JS, Cauchemez S. 2015. Influenza A virus shedding and infectivity in households. J Infect Dis 212: 14201428. doi:10.1093/infdis/jiv225

Vellozzi C, Iqbal S, Broder K. 2014. Guillain-Barré syndrome, influenza, and influenza vaccination: the epidemiologic evidence. Clin Infect Dis 58: 1149-1155. doi:10 $.1093 / \mathrm{cid} / \mathrm{ciu} 005$
Verity C, Stellitano L, Winstone AM, Andrews N, Stowe J, Miller E. 2011. Guillain-Barré syndrome and H1N1 influenza vaccine in UK children. Lancet 378: 1545-1546. doi:10.1016/S0140-6736(11)61665-6

Verstraeten T, Cohet C, Santos GD, Ferreira GLC, Bollaerts K, Bauchau V, Shinde V. 2015. Pandemrix ${ }^{\mathrm{TM}}$ and narcolepsy: a critical appraisal of the observational studies. Hum Vaccin Immunother 12: 187-193. doi:10.1080/ 21645515.2015.1068486

Vesikari T, Kirstein J, Go GD, Leav B, Ruzycky ME, Isakov L, de Bruijn, Oberye J, Heijnen E. 2018. Efficacy, immunogenicity, and safety evaluation of an MF59-adjuvanted quadrivalent influenza virus vaccine compared with non-adjuvanted influenza vaccine in children: a multicentre, randomised controlled, observer-blinded, phase 3 trial. Lancet Respir Med 6: 345-356. doi:10.1016/ S2213-2600(18)30108-5

Viboud C, Boelle PY, Cauchemez S, Lavenu A, Valleron AJ, Flahault A, Carrat F. 2004. Risk factors of influenza transmission in households. Br J Gen Pract 54: 684689.

von Essen MR, Kongsbak M, Geisler C. 2012. Mechanisms behind functional avidity maturation in T cells. Clin Dev Immunol 2012: 163453. doi:10.1155/2012/163453

Wang B, Russell ML, Moss L, Fonseca K, Earn DJ, Aoki F, Horsman G, Caeseele PV, Chokani K, Vooght M, et al. 2016. Effect of influenza vaccination of children on infection rate in Hutterite Communities: follow-up study of a randomized trial. PLOS ONE 11: e0167281. doi:10.1371/ journal.pone. 0167281

Weycker D, Edelsberg J, Halloran ME, Longini IM Jr, Nizam A, Ciuryla V, Oster G. 2005. Population-wide benefits of routine vaccination of children against influenza. Vaccine 23: 1284-1293. doi:10.1016/j.vaccine.2004.08.044

Widdowson MA, Monto AS. 2013. Epidemiology of influenza. In Textbook of influenza (ed. Webster RG, Monto AS, et al.), pp. 250-266. John Wiley, Hoboken, NJ.

Wilkinson TM, Li CK, Chui CS, Huang AK, Perkins M, Liebner JC, Lambkin-Williams R, Gilbert A, Oxford J, Nicholas B, et al. 2012. Preexisting influenza-specific $\mathrm{CD}^{+} \mathrm{T}$ cells correlate with disease protection against influenza challenge in humans. Nat Med 18: 274-280. doi: $10.1038 / \mathrm{nm} .2612$

Worby CJ, Chaves SS, Wallinga J, Lipsitch M, Finelli L, Goldstein E. 2015. On the relative role of different age groups in influenza epidemics. Epidemics 13: 10-16. doi:10.1016/j.epidem.2015.04.003

Wrammert J, Koutsonanos D, Li GM, Edupuganti S, Sui J, Morrissey M, McCausland M, Skountzou I, Hornig M, Lipkin WI, et al. 2011. Broadly cross-reactive antibodies dominate the human $B$ cell response against 2009 pandemic H1N1 influenza virus infection. J Exp Med 208: 181-193. doi:10.1084/jem.20101352

Wright PF, Hoen AG, Ilyushina NA, Brown EP, Ackerman ME, Wieland-Alter W, Connor RI, Jegaskanda S, Rosenberg-Hasson Y, Haynes BC, et al. 2016. Correlates of immunity to influenza as determined by challenge of children with live, attenuated influenza vaccine. Open Forum Infect Dis 3: ofw108. doi:10.1093/ofid/ofw108

Wu S, Metcalf JP, Wu W. 2011. Innate immune response to influenza virus. Curr Opin Infect Dis 24: 235-240. doi:10 $.1097 / \mathrm{QCO} .0 \mathrm{~b} 013 \mathrm{e} 328344 \mathrm{c} 0 \mathrm{e} 3$ 
J. Nayak et al.

Wu T, Hu Y, Lee YT, Bouchard KR, Benechet A, Khanna K, Cauley LS. 2014. Lung-resident memory CD8 T cells (TRM) are indispensable for optimal cross-protection against pulmonary virus infection. J Leukoc Biol 95: 215-224. doi:10.1189/jlb.0313180

Yang W, Elankumaran S, Marr LC. 2011. Concentrations and size distributions of airborne influenza A viruse measured indoors at a health centre, a day-care centre and on aeroplanes. $J R$ Soc Interface 8: 1176-1184. doi:10.1098/rsif.2010.0686

Yerkovich ST, Wikström ME, Suriyaarachchi D, Prescott SL, Upham JW, Holt PG. 2007. Postnatal development of monocyte cytokine responses to bacterial lipopolysaccharide. Pediatr Res 62: 547-552. doi:10.1203/PDR .0b013e3181568105

Zaman K, Roy E, Arifeen SE, Rahman M, Raqib R, Wilson E, Omer SB, Shahid NS, Breiman RF, Breiman RE, et al. 2008. Effectiveness of maternal influenza immunization in mothers and infants. $N$ Engl J Med 359: 1555-1564. doi:10.1056/NEJMoa0708630

Zambon M. 2013. Influenza surveillance and laboratory diagnosis. In Textbook of influenza (ed. Webster RG, Monto AS et al.), pp. 229-249. John Wiley, Hoboken, NJ.

Zedda L, Forleo-Neto E, Vertruyen A, Raes M, Marchant A, Jansen W, Clouting H, Arora A, Beatty ME, Galli G, et al. 2015. Dissecting the immune response to MF59adjuvanted and nonadjuvanted seasonal influenza vaccines in children less than three years of age. Pediatr Infect Dis J 34: 73-78. doi:10.1097/INF.000000000000 0465

Zens KD, Farber DL. 2016. Reduced lung-resident T cell memory in infants following influenza infection. J Immunol 196: 68.3 .

Zhong Z, Haltalli M, Holder B, Rice T, Donaldson B, O’Driscoll M, Le-Doare K, Kampmann B, Tregoning JS. 2019. The impact of timing of maternal influenza immunization on infant antibody levels at birth. Clin Exp Immuno 195: 139-152. doi:10.1111/cei.13234

Zhu W, Higgs BW, Morehouse C, Streicher K, Ambrose CS, Woo J, Kemble GW, Jallal B, Yao Y. 2010. A whole genome transcriptional analysis of the early immune response induced by live attenuated and inactivated influenza vaccines in young children. Vaccine 28: 28652876. doi:10.1016/j.vaccine.2010.01.060

Zomer TP, Erasmus V, Looman CW, Tjon-A-Tsien A, van Beeck EF, de Graaf JM, van Beeck AHE, Richardus JH, Voeten HACM. 2015. A hand hygiene intervention to reduce infections in child daycare: a randomized controlled trial. Epidemiol Infect 143: 2494-2502. doi:10 .1017/S095026881400329X 


\section{$\&_{\mathrm{CSH}}^{\infty} \&$ Cold Spring Harbor

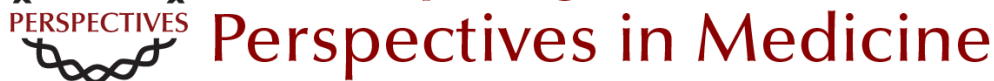

\section{Influenza in Children}

Jennifer Nayak, Gregory Hoy and Aubree Gordon

Cold Spring Harb Perspect Med 2021; doi: 10.1101/cshperspect.a038430 originally published online December 23, 2019

\section{Subject Collection Influenza: The Cutting Edge}

\section{Emerging HxNy Influenza A Viruses} William J. Liu, Yan Wu, Yuhai Bi, et al.

Equine Influenza

Thomas M. Chambers

\section{Human Influenza Epidemiology \\ Sukhyun Ryu and Benjamin J. Cowling}

Host Cell Factors That Interact with Influenza

Virus Ribonucleoproteins

Ecco Staller and Wendy S. Barclay

Induction and Evasion of Type-I Interferon

Responses during Influenza A Virus Infection

Raquel Muñoz-Moreno, Carles Martínez-Romero and Adolfo García-Sastre

Structure and Function of Influenza Polymerase Joanna M. Wandzik, Tomas Kouba and Stephen Cusack

H7N9 Influenza Virus in China Chengjun Li and Hualan Chen

\section{H5 Influenza Viruses in Egypt}

Rabeh El-Shesheny, Ahmed Kandeil, Ahmed Mostafa, et al. Antivirals Targeting the Neuraminidase
Larisa Gubareva and Teena Mohan

Accessory Gene Products of Influenza A Virus Rute M. Pinto, Samantha Lycett, Eleanor Gaunt, et al.

Influenza Immunization in the Context of

Preexisting Immunity Susanne L. Linderman, Ali H. Ellebedy, Carl Davis, et al.

Hemagglutinin Structure and Activities Steven J. Gamblin, Sébastien G. Vachieri, Xiaoli Xiong, et al.

Live Attenuated Cold-Adapted Influenza Vaccines Kanta Subbarao

Next-Generation Influenza Vaccines Masaru Kanekiyo and Barney S. Graham

Selective Genome Packaging Mechanisms of Influenza A Viruses

Takeshi Noda

Systems Biological Analysis of Immune Response to Influenza Vaccination

Mario Cortese, Amy C. Sherman, Nadine G. Rouphael, et al.

For additional articles in this collection, see http://perspectivesinmedicine.cshlp.org/cgi/collection/ 